\title{
Management of Barrett's esophagus
}

\author{
Ziad Younes $\mathrm{MD}^{1}$, Mark D Duncan $\mathrm{MD}^{2}$, John W Harmon MD ${ }^{2}$
}

Z Younes, MD Duncan, JW Harmon. Management of Barrett's esophagus. Can J Gastroenterol 2000;14(Suppl D):35D-43D. There have been major recent advances in the understanding of the pathogenesis and epidemiology of Barrett's esophagus and adenocarcinoma of the esophagus. The advent of potent acid suppression with proton pump inhibitors and safe, minimally invasive antireflux procedures has made alleviating symptoms and eliminating peptic complications achievable goals for the vast majority of patients. Endoscopic surveillance of Barrett's esophagus is considered the standard of care and is widely used in clinical practice. Neither medical nor surgical antireflux procedures, however, result in the regression of Barrett's esophagus in any consistent manner. Thermal and chemical endoscopic ablation techniques show promise in both the management of high grade dysplasia and the reversal of Barrett's esophagus, but these techniques are still of unproven benefit, and can be costly and risky. Therefore, prospective and controlled studies with long term follow-up are needed before incorporating ablative techniques into routine clinical practice. Management of high grade dysplasia remains controversial. Alternative management strategies include surveillance, resection or ablation, tailored to the individual patient and the available expertise. Targets for future research include defining appropriate surveillance intervals; finding biological markers that identify patients at higher risk of progressing to cancer; defining the cancer risk and the appropriate management of patients with short segment Barrett's esophagus; understanding the natural history of dysplasia and comparing alternatives for the management of high grade dysplasia; and studying whether surgical management can delay or prevent the progression to dysplasia and adenocarcinoma.

Key Words: Barrett's esophagus; Esophageal cancer; Gastroesophageal reflux disease (GERD)

\section{Traitement de l'oesophage de Barrett}

RÉSUMÉ : Des progrès importants ont été réalisés récemment en ce qui concerne la compréhension de la pathogenèse et l'épidémiologie de l'œsophage de Barrett et de l'adénocarcinome de l'œsophage. L'arrivée d'inhibiteurs puissants, administrés à l'aide d'une pompe à protons, visant à supprimer l'acidité ainsi que d'interventions anti-reflux sûres, peu effractives permet le soulagement des symptômes et l'élimination de complications gastriques chez la plupart des patients. La surveillance endoscopique de l'œsophage de Barrett est considérée comme la norme de soins et est largement répandue en pratique clinique. Toutefois, ni le traitement médical ni les interventions anti-reflux n'assurent une régression durable de l'œsophage de Barrett. Les techniques d'ablation thermiques ou chimiques par endoscopie s'avèrent prometteuses tant pour le traitement de la dysplasie avancée que pour la régression de l'œsophage de Barrett, mais elles n'ont pas fait encore leurs preuves et elles peuvent être coûteuses et risquées. Des études prospectives, contrôlées, avec suivi à long terme doivent donc être réalisées avant l'intégration des techniques d'ablation dans la pratique clinique courante. Le traitement de la dysplasie avancée suscite toujours la controverse. Il existe différentes stratégies de traitement, dont la surveillance, la résection ou l'ablation, adaptées aux besoins des patients et à l'expertise en place. Parmi les objets de futures recherches, mentionnons la détermination des intervalles appropriés de surveillance, la découverte de marqueurs biologiques témoignant d'un risque élevé de cancérisation, l'évaluation du risque de cancer et le traitement approprié de l'œsophage de Barrett à segment court, la compréhension de l'évolution naturelle de la dysplasie et la comparaison de diverses thérapies pour le traitement de la dysplasie avancée ainsi que l'évaluation des traitements chirurgicaux à l'égard de l'apparition tardive ou même de la prévention de la dysplasie et de l'adénocarcinome.

\section{BACKGROUND}

Barrett's esophagus is an acquired condition characterized by the replacement of the squamous lining of the esophagus by metaplastic columnar epithelium. This condition is re- ceiving increasing attention because it appears to be the precursor for most cases of esophageal adenocarcinoma. Attention is further heightened by the incidence of adenocarcinoma of the esophagus, which has risen dramatically

This mini-review was prepared from a presentation made at the 1998 World Congress of Gastroenterology, 1998, Vienna, Austria, September 6 to 11 Departments of ${ }^{1}$ Internal Medicine and ${ }^{2}$ Surgery, The Johns Hopkins University School of Medicine, Johns Hopkins Bayview Medical Center, Baltimore, Maryland, USA

Correspondence: Dr JW Harmon, Section of Surgical Sciences, Johns Hopkins Bayview Medical Center, 4940 Eastern Avenue, Baltimore, Maryland 21224, USA. Telephone 410-550-0400, fax 410-550-1245, e-mail jharmon@jhmi.edu

Received for publication June 9, 1999. Accepted June 13, 1999 
during the past two decades in the United States and the Western world (1-3).

The definition of Barrett's esophagus has evolved considerably over the years (4). Currently, the most widely accepted definition of Barrett's esophagus is a "change in the esophageal epithelium of any length that can be recognized by endoscopy and is confirmed to have intestinal metaplasia by biopsy" (5). This recognizes several key points. First, intestinal-type metaplasia needs to be present, because it is the lesion that is associated with adenocarcinoma and requires surveillance (6). Second, a major emphasis is placed on endoscopic recognition, allowing a distinction between Barrett's esophagus and intestinal metaplasia at the gastroesophageal junction. The latter condition is very common (7) and does not have a clear-cut association with gastroesophageal reflux $(8,9)$, and its progression to dysplasia and adenocarcinoma is not well defined (9). Third, the length of the Barrett's segment is not crucial; even short segment Barrett's cases carry a substantial (though possibly lower) risk of progression toward dysplasia and adenocarcinoma (10-12).

\section{EPIDEMIOLOGY OF BARRETT'S ESOPHAGUS AND ADENOCARCINOMA}

Most epidemiological studies of Barrett's esophagus have focused on patients with a long segment of columnar epithelium. Studies on the prevalence of Barrett's esophagus have yielded variable results because of differences in design and referral bias, and because patients with Barrett's esophagus often have minimal symptoms (13). Although retrospective reviews demonstrated a prevalence of Barrett's esophagus of $10 \%$ to $20 \%$ of patients undergoing endoscopy for reflux symptoms, prospective data revealed that only $3 \%$ to $5 \%$ of patients with weekly or daily heartburn have Barrett's esophagus (14). The autopsy rate for Barrett's esophagus was 1\% in Olmsted County, Minnesota, United States; this translates into an age-adjusted 'true' prevalence that is 17 times higher than the clinically diagnosed prevalence in the same county during the same period (15). These data infer that the vast majority of patients with Barrett's esophagus remain undiagnosed.

The prevalence of Barrett's esophagus and esophageal adenocarcinoma increases with age. The median age for developing Barrett's esophagus has been estimated at 40 years, while the mean age of diagnosis is 63 years (16). Both Barrett's esophagus and esophageal adenocarcinoma are predominantly male diseases, with a male to female ratio of approximately two to one and eight to one, respectively (14). Esophageal adenocarcinoma is more prevalent in white than in black Americans (1).

The vast majority of esophageal adenocarcinomas appear to arise from Barrett's esophagus. Reports are variable as to the incidence of adenocarcinoma in patients with Barrett's esophagus. A review of 18 available series estimated the incidence of cancer in patients with Barrett's esophagus to be one/100 years of patient follow-up (17). More recent studies with a longer duration of follow-up have found a cancer incidence of one/180 to 208 years of patient follow-up (18-20).

\section{PATHOGENESIS OF BARRETT'S ESOPHAGUS}

The controversy as to the etiology of Barrett's esophagus persisted until a landmark study demonstrated columnar regeneration in a dog model following severe mucosal injury from chronic gastroesophageal reflux (21). Further studies suggested that the population of metaplastic cells in Barrett's esophagus develop from multipotential cells present in the basal layer of the esophageal mucosa $(22,23)$. The exact pathogenesis of Barrett's esophagus and esophageal adenocarcinoma, however, remains unknown. Substantial experimental and clinical evidence support the importance of gastroesophageal reflux in causing esophageal mucosal injury and predisposing the development of Barrett's esophagus $(21,24,25)$. Barrett's esophagus represents the severe end on the spectrum of reflux disease. However, studies have shown that the degree of acid reflux and esophageal motor abnormalities is similar in patients with Barrett's esophagus and patients with severe esophagitis without Barrett's esophagus (26). This suggests that additional factors are important in the development of Barrett's esophagus.

Reflux of duodenal contents, particularly bile acids, may contribute to the development of Barrett's esophagus. It is well recognized that bile, particularly in conjunction with acid and pepsin, can cause disruption of the mucosal barrier in the esophageal epithelium and accentuate the degree of esophagitis $(27,28)$. The majority of patients with Barrett's esophagus have increased exposure to both acid reflux and reflux of bile acids (29-31). Furthermore, the severity of bile reflux was found to parallel acid reflux, rising in a graded manner from low levels in controls, to higher levels in patients with mild esophagitis, to even higher in patients with severe esophagitis and Barrett's esophagus (32). Laboratory studies have shown that bile acids can become concentrated in the esophageal mucosa, up to 14 times the luminal concentration while in the presence of acid. This process is driven by the physiochemical forces related to the presence of a weak acid (bile) at an interface between an acid (luminal) and a neutral (cellular) interface (33). The role of bile reflux in the absence of excessive acid reflux is unclear. Although animal experimental models have suggested that isolated bile reflux may increase the risk of adenocarcinoma (34), studies of symptomatic postgastrectomy patients have shown that bile reflux does not cause endoscopic esophagitis unless there is concomitant acid reflux (35). Both medical therapy for reflux disease with potent antisecretory agents $(36,37)$ and surgical therapy for reflux (38) can lower the amount of bile reflux.

Genetic factors may play a role in the development of Barrett's esophagus. It has been recently reported that relatives of patients with Barrett's esophagus and esophageal adenocarcinoma have a greater likelihood than controls of having gastroesophageal reflux disease (GERD) or Barrett's esophagus $(39,40)$.

Newer insight into the pathogenesis of Barrett's esophagus and esophageal adenocarcinoma may arise from the study of growth factors. The most studied growth factor system is that of the epidermal growth factor (EGF) (41). EGF, 
the related transforming growth factor-alpha and their receptor are all overexpressed in patients with Barrett's esophagus, and particularly in patients with dysplasia and adenocarcinoma $(42,43)$. The levels of EGF and transforming growth factor-alpha in the gastric juice are three times higher in patients with Barrett's esophagus compared with patients with nonulcer dyspepsia (44). It is not yet known whether this increased exposure to EGF causes or is merely associated with Barrett's esophagus.

Another breakthrough came from the recent discovery of a transcription factor that is specific for the intestinal-type epithelium CDX-1. Despite its absence of expression in normal gastric and esophageal epithelium, CDX-1 is excessively transcribed in intestinal metaplasia of the esophagus and stomach (45). Further understanding of the biological activity of CDX-1 may provide key information on the pathogenesis of Barrett's esophagus.

Another recent area of interest is the association of Barrett's esophagus with the impairment of the mechanism for bioactive compound detoxification. Barrett's epithelium has been shown to have a significantly lower glutathione content and lower glutathione-S-transferase (GST) enzyme activity compared with normal esophageal epithelium (46). The same research group recently studied polymorphism in genes for enzymes controlling drug metabolism and detoxification (including the GSTP1 gene). Patients with Barrett's esophagus and esophageal adenocarcinoma were more likely to express the polymorphic variant GSTP1b (47) than healthy blood donors. The occurrence of GSTP1b resulted in significantly lower GST enzyme activity.

\section{PROGRESSION FROM METAPLASIA TO ADENOCARCINOMA}

The progression from Barrett's esophagus to esophageal adenocarcinoma is also poorly understood. It is well accepted that esophageal adenocarcinoma is the result of progressive cellular and biological changes from nondysplastic Barrett's esophagus, to advancing degrees of dysplasia, and finally to invasive adenocarcinoma. The biological mechanisms underlying this progression are the subject of intense research efforts. Although several biomarkers, such as proliferation indexes, DNA-ploidy and p53 abnormalities, are being investigated (48-50), very limited data are currently available to make any recommendations as to their potential clinical management utility. It is hoped that a prospective tissue bank for Barrett's esophagus (51) and the subsequent testing of biomarkers will help to identify those markers useful in the management of Barrett's.

\section{MANAGEMENT OF BARRETT'S ESOPHAGUS}

There are several goals involved in the management of Barrett's esophagus. These include: first, control of reflux symptoms; second, healing of esophagitis; and third, surveillance for early detection of dysplasia and cancer (5). Goals that remain elusive include stopping the progression of Barrett's esophagus and promoting the reversal of Barrett's esophagus and dysplasia. The tools available to contribute to achieving
TABLE 1

Recommendations for endoscopic surveillance for Barrett's esophagus

\begin{tabular}{lc}
\hline Dysplasia & Proposed follow-up \\
\hline None & $\begin{array}{c}\text { After two negative endoscopies, every two } \\
\text { to three years } \\
\text { Indeterminate }\end{array}$ \\
$\begin{array}{c}\text { Surveillance after three to six months of } \\
\text { aggressive medical therapy } \\
\text { Low grade } \\
\text { High grade }\end{array}$ & $\begin{array}{c}\text { Expert confirmation followed by resection, } \\
\text { intensive surveillance protocol every } \\
\text { three months for one year and then } \\
\text { every six to 12 months or ablation as } \\
\text { part of a trial } \\
\text { Insufficient data to make recommendations; } \\
\text { short segment Barrett's } \\
\text { esophagus without } \\
\text { dysplasia }\end{array}$ \\
\hline
\end{tabular}

these goals are endoscopic surveillance, medical therapy, surgical therapy and endoscopic ablative techniques. It should be remembered that reversal of Barrett's esophagus must be complete to be meaningful, because the ultimate goal is the prevention of adenocarcinoma, and dysplasia can progress to adenocarcinoma even with partial regression of the Barrett's mucosa (52). Recent preliminary studies have shown that full reversal to squamous mucosa resulted in normalization of both the cell cycle and the proliferation abnormalities associated with Barrett's esophagus. However, when only partial regression of the columnar epithelium was achieved, these cell cycle and proliferation abnormalities persisted $(53,54)$. It has also been reported that residual Barrett's mucosa following 'ablative' therapy progresses to dysplasia in one-third of the cases over an average of two years (55).

Surveillance: The rationale for surveillance is that patients with Barrett's esophagus are at an increased risk of developing adenocarcinoma. Adenocarcinoma of the esophagus has a dismal prognosis when diagnosis is delayed until patients develop symptoms such as dysphagia. Preliminary reports suggest that those adenocarcinomas detected during surveillance for Barrett's are at an earlier stage, affording patients better survival $(56,57)$. Because the goal of surveillance is to detect the presence of dysplasia, multiple, systematic (four-quadrant) biopsies of the metaplastic segment should be obtained. This is best done after healing of erosive esophagitis to minimize the effect of active inflammation, because inflammation can cause histological atypia, which can be misinterpreted as dysplasia. In addition to the biopsies obtained from normal appearing Barrett's epithelium, any mucosal abnormality should be extensively biopsied. Newer techniques such as mucosal staining with methylene blue may increase the detection of dysplasia and, therefore, make surveillance more efficient (58). The appropriate intervals for endoscopic surveillance are still empirical because they have not been rigorously tested (Table 1 ). Recent practice guidelines sponsored by the American College of Gastroenterology recommend follow-up endoscopy every two to three years after two yearly endoscopies fail to 
show dysplasia. If low grade dysplasia is diagnosed, endoscopic surveillance is recommended every six months for one year and then yearly if there is no progression (5). Although the value of surveillance in patients with Barrett's has been criticized (18), endoscopic surveillance has been adopted in clinical practice (59). The follow-up of patients with short segment Barrett's (ie, less than $3 \mathrm{~cm}$ ) is controversial. The surveillance intervals are unclear, and firm recommendations await additional information on the cancer risk in patients with short segment Barrett's (5). The management and follow-up of patients with high grade dysplasia (see below) are even more controversial because there are no controlled studies comparing the different options.

Medical therapy: Medical therapy has focused primarily on the control of GERD symptoms and the healing of esophagitis. Because Barrett's esophagus appears to be a severe form of chronic GERD, aggressive management of GERD is appropriate. Lifestyle changes are extremely important in this patient population. These include the avoidance of large and late meals; weight management; avoidance of tobacco, alcohol and coffee; and elevation of the head of the bed. Abstinence from alcohol and tobacco is particularly important because both may be associated with a higher incidence of adenocarcinoma (60). Treatment with $\mathrm{H}_{2}$ receptor antagonists can improve reflux symptoms and heal the majority of erosive esophagitis and ulceration cases (61). More recently, proton pump inhibitors were shown to be superior to $\mathrm{H}_{2}$ receptor antagonists in the treatment and maintenance of patients with Barrett's-associated ulcers and severe esophagitis $(62,63)$. Patients with Barrett's esophagus have, as a group, greater esophageal exposure to reflux than usual GERD patients (64) and can require higher doses of potent acidlowering medications for the control of acid reflux (65). Even though medical therapy can control GERD symptoms and heal esophagitis, it does not appear that a significant regression of Barrett's can be achieved with either $\mathrm{H}_{2}$ receptor antagonists or proton pump inhibitors (66-68).

Surgical antireflux therapy: Using antireflux therapy for GERD has increased considerably in the past five years, after the introduction of laparoscopic techniques. Surgical therapy is particularly appealing for patients with Barrett's esophagus because many of them require long term treatment with potent medical therapy. Surgical therapy has a theoretical advantage in that it can control reflux of all forms of gastric contents into the esophagus; for example, surgical therapy has been shown to be superior to medical therapy in controlling duodenogastroesophageal reflux $(69,70)$. Antireflux procedures have been shown, in most studies, to offer very good symptomatic relief in patients with Barrett's mucosa and to heal erosive esophagitis (71). Although initial reports suggested that antireflux procedures could cause regression of Barrett's esophagus (72), recent studies have failed to confirm this finding (73-75). In most series, the regression of the Barrett's changes was incomplete. Measuring the regression of Barrett's may be inaccurate, because antireflux operations typically bring the esophagogastric junction into the abdomen, thus shifting the squamocolumnar junc- tion distally. The effect of antireflux procedures on the fate of dysplasia has also been variable, with studies showing progression of dysplasia in some patients and regression or apparent prevention in others $(20,76)$. There remains interest in the possibility that antireflux surgery can prevent or retard the development of adenocarcinoma in patients with Barrett's esophagus. Nonetheless, it is well documented that adenocarcinoma can develop after antireflux procedures $(72,73,77-80)$, and it is recommended that patients with Barrett's remain enrolled in endoscopic surveillance after surgical management. Investigators from the Mayo Clinic have reported long term follow-up on patients with Barrett's esophagus who underwent antireflux surgery. Although three patients developed adenocarcinoma, all cancers were diagnosed within the first three years following surgery. There were no additional cancers that developed despite a follow-up period of up to 18 years (mean 6.5 years) (79). This suggests that the patients in the Mayo series who developed cancer already had severe dysplasia or even carcinoma in situ before surgical intervention. In another report, adenocarcinomas developed years after antireflux surgery in patients with recurrent reflux after surgical failures (80).

The authors believe, based on the available evidence, that the indications for antireflux surgery in patients with Barrett's esophagus should be similar to those for patients with severe GERD: surgical therapy is indicated for symptomatic relief in patients with documented reflux disease and poor response to medical therapy, as well as in young patients as an alternative to long term acid suppressive therapy. It is important to continue endoscopic and histological surveillance postoperatively for these patients. It is conceivable that the indications for surgical management may broaden as more information is obtained on the pathogenesis of Barrett's esophagus and if prospective studies demonstrate that surgical management affects cancer development. Such prospective clinical investigations are urgently needed. In addition, surgical antireflux procedures, which reduce esophageal acid exposure to normal, may be coupled with endoscopic ablative techniques as a novel approach to reversing Barrett's metaplasia (81).

Management of high grade dysplasia: The optimal management of Barrett's esophagus patients with high grade dysplasia remains particularly controversial. Most surgical series suggest esophagectomy once high grade dysplasia is documented, citing a $40 \%$ to $50 \%$ incidence of finding invasive adenocarcinoma in the surgical specimens $(82-87)$. Surgical resection is generally curative for mucosal and submucosal $\left(T_{1}\right)$ lesions. The mortality rate for esophagectomy by experts in Barrett's esophagus is acceptably low at $4 \%$ or less, although there is still a high morbidity rate (85). Late complications often involve anastomotic strictures, which can be managed with dilation (84). Resection also eliminates the subsequent need for endoscopic surveillance or medical acid suppression. Esophagectomy in patients with Barrett's and high grade dysplasia is arguably more appropriate than for the majority of patients with invasive cancer, for whom the prognosis remains dismal despite surgery. Either a transthoracic or transhiatal approach 


\section{COPYRIGHT PULSUS GROUP INC, - DO NOT̈ COPY}

may be used. Transhiatal esophagectomy has achieved excellent results in this patient population and is the procedure of choice when resective surgery is required (86). Most of these studies, however, were retrospective in nature, did not provide a full description of the endoscopic findings and did not follow a strict preoperative endoscopic biopsy protocol. Some series included patients with dysphagia and endoscopic findings such as nodularity. Other investigators have challenged these findings by reporting that a strict endoscopic biopsy protocol can successfully differentiate between adenocarcinoma and high grade dysplasia (88). Investigators have reported that patients defined as having high grade dysplasia by this protocol can undergo endoscopic surveillance and have a lower rate of cancer (88-90). The American College of Gastroenterology practice guidelines recommend expert pathological confirmation for high grade dysplasia and give two management alternatives: surgical resection or endoscopy every three months (with surgery reserved for frank malignancy) (5). The recent introduction of endoscopic ablation techniques further complicates the management of high grade dysplasia.

The authors suggest that the decision to proceed with surgical resection for high grade dysplasia should consider the patient's physiological condition, and the expertise of available pathological, surgical and gastroenterological care. Patients with high grade dysplasia detected in a nodular lesion should undergo resective surgery, younger patients with minimal comorbidity should probably undergo resective surgery, and older patients with comorbid illnesses may be enrolled in strict surveillance or endoscopic ablation as part of an ongoing research trial.

Endoscopic ablation: The rationale for endoscopic ablation is relatively straightforward: the goal is to ablate the columnar mucosa and allow it to heal as normal squamous mucosa. GERD control, either by medical or surgical therapy, is necessary as an adjunct to ablation. Endoscopic ablation has been used in the esophagus to reverse intestinal metaplasia, eliminate dysplasia, cure early cancer and palliate advanced cancer. It is important to note that endoscopic ablation for the therapy of Barrett's esophagus is still considered experimental and should be used only as part of research protocol or in patients who have comorbidities judged to preclude surgery or who refuse surgery $(91,92)$. A variety of techniques have been described, and these can be broadly divided into thermal, chemical or mechanical ablation. Thermal ablation can be accomplished with the use of a variety of lasers (neodymium:yttrium-aluminum-garnet laser, the potassiumtitanyl-phosphate laser, the argon laser), multipolar electrocoagulation, argon beam plasma coagulation and cryotherapy using a cryospray catheter. Chemical ablation has been performed with photodynamic therapy (PDT), using primarily porfimer sodium or 5-aminolevulonic acid. Mechanical ablation is performed with endoscopic mucosal resection (EMR). EMR can be achieved by a 'suck and cut' or 'lift and cut' method (93). EMR has been mostly used in the management of early esophageal cancer and has limited usefulness in the management of Barrett's esophagus and dysplasia unless high grade dysplasia is very focal in nature. Because of these
Table 2

Comparison of ablative methods for treatment of Barrett's esophagus

\begin{tabular}{lcccc}
\hline Ablative method & $\begin{array}{c}\text { Depth of } \\
\text { injury }\end{array}$ & $\begin{array}{c}\text { Sessions } \\
\text { needed }\end{array}$ & $\begin{array}{c}\text { Side } \\
\text { effects }\end{array}$ & Cost \\
\hline Nd:YAG laser & +++ & One to two & ++ & +++ \\
Argon laser & + & Multiple* & + & +++ \\
KTP laser & ++ & Two to three & ++ & +++ \\
PDT & +++ & One to two & +++ & +++ \\
MPEC & + & Multiple* & + & + \\
APC & + & Multiple* & + & ++ \\
\hline
\end{tabular}

+ to +++ Least to greatest; ${ }^{*}$ More than three sessions. APC Argon plasma coagulation; KTP Potassium-titanyl-phospate; MPEC Multipolar electrocoagulation; Nd:YAG Neodymium:yttrium-aluminum-garnet; PDT Photodynamic therapy

limitations, the remainder of the discussion will focus on the thermal and chemical modalities.

The choice of an ablative technique depends on the characteristics of the technique (ie, depth of injury), the lesion to treat (ie, length of the Barrett's esophagus and presence of dysplasia), the costs and the available expertise (92). Table 2 summarizes the different characteristics of each method. PDT is, so far, the only method that allows for therapy of a large area in a single firing; all other methods can treat only a small area with each firing. PDT is, therefore, easier to use and requires fewer sessions in patients with longer segments of metaplasia, particularly with the advent of elongated cylindrical diffusers with centring balloons. Depth of injury is paramount in determining both the efficacy and side effect profile of each technique. Deep injury is most likely needed to eliminate high grade dysplasia or early cancer. It is, however, associated with a higher incidence of complications, particularly stricture formation. Because the mucosa is thicker in the presence of advanced dysplasia, PDT or laser therapy is probabably superior to argon beam plasm coagulation or multipolar electrocoagulation in patients with high grade dysplasia.

Interpretation of the results of endoscopic ablation is limited by the absence of well conducted studies. The available reports are limited by a lack of controls, small numbers of patients, variable and generally short durations of follow-up, poor characterizations of patient characteristics and the combination of patients with and without dysplasia. Because the goals of treatment differ in patients with and without high grade dysplasia, the results are summarized separately where possible. Tables 3 and 4 summarize the results of selected studies on ablative therapies in patients with and without high grade dysplasia. The largest published study with endoscopic ablation describes using PDT with porfimer sodium as the photosensitizer. Overholt et al (94) presented their results of 100 patients with Barrett's esophagus and dysplasia. Thirteen patients also had early cancer, 73 patients had high grade dysplasia and 14 patients had low grade dysplasia. With follow-up ranging from four to 84 months, three patients had residual cancers and 17 patients had residual dysplasia. Barrett's esophagus was completely eliminated in $43 \%$ 
TABLE 3

Results of ablation therapy for high grade dysplasia and early adenocarcinoma

\begin{tabular}{|c|c|c|c|c|c|c|}
\hline $\begin{array}{l}\text { Author } \\
\text { (reference) }\end{array}$ & Treatment & $\begin{array}{c}\text { Number of } \\
\text { patients }\end{array}$ & $\begin{array}{l}\text { Follow-up } \\
\text { (month) }\end{array}$ & $\begin{array}{c}\text { Number of } \\
\text { patients with } \\
\text { residual dysplasia }\end{array}$ & $\begin{array}{l}\text { Number of } \\
\text { patients with } \\
\text { residual BE }\end{array}$ & Remarks \\
\hline Barr et al (95) & PDT with ALA & 5 (HGD) & 26 to 44 & 0 & 4 & \\
\hline Ortner et al (96) & PDT with ALA & $\begin{array}{l}9 \text { (various } \\
\text { dysplasia) }\end{array}$ & $\begin{array}{c}\text { Not } \\
\text { described }\end{array}$ & 2 & 7 & ALA given as a spray \\
\hline Wang et al (97) & PDT with HpD & $\begin{array}{l}75 \text { (32 LGD, } \\
23 \text { ND, } 9 \text { HGD) }\end{array}$ & 25 & 5 & 68 & \\
\hline Gossner et al (98) & PDT with ALA & $\begin{array}{c}32 \text { (22 cancer, } \\
10 \text { HGD) }\end{array}$ & 1 to 26 & 0 & 13 & $\begin{array}{l}17 \text { of } 22 \text { cancer patients and } 10 \text { of } 10 \\
\text { HGD patients are in remission }\end{array}$ \\
\hline Gossner et al (99) & KTP laser & $\begin{array}{l}10 \text { (2 cancer, } \\
4 \text { HGD, } 4 \text { LGD) }\end{array}$ & 10.6 & 0 & 2 & \\
\hline Overholt et al (94) & PDT with DHE & $\begin{array}{c}100 \text { (73 HGD, } \\
14 \text { LGD, } \\
13 \text { cancer })\end{array}$ & 4 to 84 & 17 & 57 & $\begin{array}{l}\text { Three patients had residual cancer; two } \\
\text { patients developed subsquamous } \\
\text { HGD; one patient developed cancer; } \\
34 \text { patients developed stricture; } \\
\text { Nd:YAG was used to treat residual BE }\end{array}$ \\
\hline
\end{tabular}

ALA 5-Aminolevulinic acid; BE Barrett's esophagus; DHE Dihematoporphyrin esther (photofrin); HGD High grade dysplasia; HpD Hematoporphyrin derivative; KTP Potassium-titanyl-phosphate; LGD Low grade dysplasia; ND No dysplasia; Nd:YAG Neodymium:yttrium-aluminum-garnet; PDT Photodynamic therapy

TABLE 4

Results of studies performing ablation therapy to treat Barrett's esophagus

\begin{tabular}{|c|c|c|c|c|c|}
\hline Authors (reference) & Treatment & $\begin{array}{c}\text { Number of } \\
\text { patients }\end{array}$ & $\begin{array}{l}\text { Follow-up } \\
\text { (months) }\end{array}$ & $\begin{array}{l}\text { Number of patients with } \\
\text { residual BE }\end{array}$ & Remarks \\
\hline Sampliner et al (100) & MPEC & 10 & 10 to 18 & 0 & $\begin{array}{l}\text { Half were circumferentially treated, half were } \\
\text { control group }\end{array}$ \\
\hline Guelrud and Herrara (101) & MPEC & 21 & 12 & 2 & \\
\hline Van Laetham et al (102) & APC & 31 & 3 to 12 & 20 & \\
\hline Byrne et al (103) & APC & $\begin{array}{c}30 \text { (4 LGD, } \\
3 \text { HGD) }\end{array}$ & 6 to 8 & 9 & Complications: two perforations \\
\hline Luman et al (104) & Nd:YAG laser & 4 & 8 & 0 & Randomized, prospective study \\
\hline Krevski et al (105) & Nd:YAG laser & 15 & 2 & 4 & Complications: one perforation, one stricture \\
\hline Salo et al (81) & Nd:YAG laser & 11 & 6 to 52 & 0 & Laser was coupled with antireflux surgery \\
\hline Berenson et al (106) & Argon laser & 10 & 8 & $\begin{array}{l}\text { Regression occurred in } \\
38 \text { of } 40 \text { patients }\end{array}$ & Results were expressed per 'treated area' \\
\hline Barham et al (107) & KTP laser & 13 & 3 to 18 & 9 & \\
\hline
\end{tabular}

APC Argon plasma coagulator; BE Barrett's esophagus; FU Follow-up; HGD High grade dysplasia; KTP Potassium-titanyl-phosphate; LGD Low grade dysplasia; MPEC Multipolar electrocoagulation; Nd:YAG Neodymium:yttrium-aluminum-garnet

of the patients. During the follow-up period, two patients developed high grade dysplasia and one patient developed overt carcinoma beneath normal appearing squamous mucosa. The eodymium:yttrium-aluminum-garnet laser was used to treat residual areas of Barrett's and dysplasia. Strictures requiring dilation developed in 34 patients. The authors assert that the newer diffusers offer several advantages that could increase the efficiency of the technique and reduce the stricture rate; with long diffusers and a centring balloon, a larger area of Barrett's can be evenly treated in one setting. This will obviate the need for multiple applications and should lessen the strictures that typically develop in areas of overlap.

\section{CONCLUSIONS}

Despite major advances in the understanding of Barrett's esophagus, its management remains difficult and many areas are still controversial. Advances in medical and surgical man- agement have made alleviating symptoms and eliminating peptic complications achievable goals for the vast majority of patients. Neither medical nor surgical antireflux therapy, however, has resulted in the regression of Barrett's esophagus or the prevention of adenocarcinoma in any consistent manner. The possibility that antireflux surgery retards the progression from Barrett's esophagus to adenocarcinoma needs to be tested in a well designed, clinical trial. Endoscopic ablation techniques show promise in both the management of high grade dysplasia and the reversal of Barrett's esophagus. Doctors should wait for the results of prospective and controlled studies with longer follow-up before incorporating ablative techniques into routine clinical practice. Surgical resection remains the standard against which modalities must be measured when high grade dysplasia or adenocarcinoma are present. Management of high grade dysplasia, as noted, requires the consideration of surveillance or resection tailored to the 
individual patient and the available expertise. Future research is also needed to define better appropriate surveillance intervals, to find biological markers that identify patients at higher risk of progression toward cancer, and to define the cancer risk and the appropriate management of patients with short segment Barrett's esophagus.

\section{REFERENCES}

1. Blot WJ, Devesa SS, Kneller RW, Fraumeni JF Jr. Rising incidence of adenocarcinoma of the esophagus and gastric cardia. JAMA 1991;265:1287-9.

2. Pera M, Cameron AJ, Trastek VF, Carpenter HA, Zinsmeister AR. Increasing incidence of adenocarcinoma of the esophagus and esophagogastric junction. Gastroenterology 1993;104:510-3.

3. Bytzer P, Christensen PB, Damkier P, Vinding K, Seersholm N. Adenocarcinoma of the esophagus and Barrett's esophagus: a population-based study. Am J Gastroenterol 1999;94:86-91.

4. Spechler SJ, Goyal RK. The columnar-lined esophagus, intestinal metaplasia, and Norman Barrett. Gastroenterology 1996;110:614-21.

5. Sampliner RE. Practice guidelines on the diagnosis, surveillance, and therapy of Barrett's esophagus. The Practice Parameters Committee of the American College of Gastroenterology. Am J Gastroenterol 1998;93:1028-32.

6. Weinstein WM, Ippoliti AF. The diagnosis of Barrett's esophagus: goblets, goblets, goblets. Gastrointest Endosc 1996;44:91-5.

7. Spechler SJ, Zeroogian JM, Antonioli DA, Wang HH, Goyal RK. Prevalence of metaplasia at the gastro-oesophageal junction. Lancet 1994;344:1533-6.

8. Pereira AD, Suspiro A, Chavez P, et al. Short segments of Barrett's epithelium and intestinal metaplasia in normal appearing oesophagogastric junctions: the same or two different entities? Gut 1998;42:659-62.

9. Hirota WK, Loughney TM, Lazas DJ, Maydonovitch CL, Rholl V, Wong RK. Specialized intestinal metaplasia, dysplasia, and cancer of the esophagus and esophagogastric junction: prevalence and clinical data. Gastroenterology 1999;116:277-85.

10. Schnell TG, Sontag SJ, Chejfec G. Adenocarcinomas arising in tongues or short segments of Barrett's esophagus. Dig Dis Sci 1992;37:137-43.

11. Weston AP, Krmpotich PT, Cherian R, Dixon A, Topalosvki M. Prospective long-term endoscopic and histological follow-up of short segment Barrett's esophagus: comparison with traditional long segment Barrett's esophagus. Am J Gastroenterol 1997;92:407-13.

12. Sharma P, Morales TG, Bhattacharyya A, Garewal HS, Sampliner RE. Dysplasia in short-segment Barrett's esophagus: a prospective 3-year follow-up. Am J Gastroenterol 1997;92:2012-6.

13. Winters C Jr, Spurling TJ, Chobanian SJ, et al. Barrett's esophagus: a prevalent, occult complication of gastroesophageal reflux disease. Gastroenterology 1987;92:118-24.

14. Cameron AJ. Epidemiology of columnar-lined esophagus and adenocarcinoma. Gastroenterol Clin North Am 1997;26:487-94.

15. Cameron AJ, Zinsmeister AR, Ballard DJ, Carney JA. Prevalence of columnar-lined (Barrett's) esophagus. Comparison of population-based clinical and autopsy findings. Gastroentology 1990;99:918-22.

16. Cameron AJ, Lomboy CT. Barrett's esophagus: age, prevalence, and extent of columnar epithelium. Gastroenterology 1992;103:1241-5.

17. Tytgat GN. Does endoscopic surveillance in esophageal columnar metaplasia (Barrett's esophagus) have any real value? Endoscopy 1995;27:19-26.

18. Van der Burgh A, Dees J, Hop WC, van Blankenstein M. Oesophageal cancer is an uncommon cause of death in patients with Barrett's oesophagus. Gut 1996;39:5-8.

19. Drewitz DJ, Sampliner RE, Garewal HS. The incidence of adenocarcinoma in Barrett's esophagus: a prospective study of 170 patients followed 4.8 years. Am J Gastroenterol 1997;92:212-5.

20. Katz D, Rothstein R, Schned A, Dunn J, Seaver K, Antonioli D. The development of dysplasia and adenocarcinoma during endoscopic surveillance of Barrett's esophagus. Am J Gastroenterol 1998;93:536-41.

21. Bremner CG, Lynch VP, Ellis FH Jr. Barrett's esophagus: congenital or acquired? An experimental study of esophageal mucosal regeneration in the dog. Surgery 1970;68:209-16.

22. Gillen P, Keeling P, Byrne PJ, Healy M, West AB, Hennessy TP.
Experimental columnar metaplasia in the canine oesophagus. Br J Surg 1988;75:113-5.

23. Boch JA, Shields HM, Antonioli DA, Zwas F, Sawhney RA, Trier JS. Distribution of cytokeratin markers in Barrett's specialized columnar epithelium. Gastroenterology 1997;112:760-5.

24. Stein HJ, Hoeft S, DeMeester TR. Reflux and motility patterns in Barrett's esophagus. Dis Esophagus 1992;5(Suppl):21-8.

25. Gillen P, Keeling P, Byrne PJ, Hennessy TP. Barrett's oesophagus: pH profile. Br J Surg 1987;74:774-6.

26. Coenraad M, Masclee AA, Straathof JW, Ganesh S, Griffioen G, Lamers CB. Is Barrett's esophagus characterized by more pronounced acid reflux than severe esophagitis? Am J Gastroenterol 1998;93:1068-72.

27. Harmon JW, Johnson LF, Maydonovitch CL. Effects of acid and bile salts on the rabbit esophageal mucosa. Dig Dis Sci 1981;26:65-72.

28. Lillemoe KD, Johnson LF, Harmon JW. Alkaline esophagitis: a comparison of the ability of components of gastroduodenal contents to injure the rabbit esophagus. Gastroenterology 1983;85:621-8.

29. Vaezi MF, Richter JE. Role of acid and duodenogastroesophageal reflux in gastroesophageal reflux disease. Gastroenterology 1996;111:1192-9.

30. Kauer WK, Peters JH, DeMeester TR, Ireland AP, Bremner CG, Hagen JA. Mixed reflux of gastric and duodenal juices is more harmful to the esophagus than gastric juice alone. The need for surgical therapy re-emphasized. Ann Surg 1995;222:525-33.

31. Caldwell MT, Lawlor P, Byrne PJ, Walsh TN, Hennessy TP. Ambulatory oesophageal bile reflux monitoring in Barrett's esophagus. Br J Surg 1995;82:657-60.

32. Vaezi MF, Richter JE. Synergism of acid and duodenogastroesophageal reflux in complicated Barrett's esophagus. Surgery 1995;117:699-704.

33. Schweitzer EJ, Bass BL, Batzri S, Young P, Huesken J, Harmon JW. Lipid solubilization during bile salt-induced esophageal mucosal barrier disruption in the rabbit. J Lab Clin Med 1987;110:172-9.

34. Ireland AP, Peters JH, Smyrk TC, et al. Gastric juice protects against the development of esophageal adenocarcinoma in the rat. Ann Surg 1996;224:358-71.

35. Sears RJ, Champion GL, Richter JE. Characteristics of distal partial gastrectomy patients with esophageal symptoms of duodenogastric reflux. Am J Gastroenterol 1995;90:211-5.

36. Champion G, Richter JE, Vaezi MF, Singh S, Alexander R. Duodenogastroesophageal reflux: relationship to $\mathrm{pH}$ and importance in Barrett's esophagus. Gastroenterology 1994;107:747-54.

37. Marshall RE, Anggiansah A, Manifold DK, Owen WA, Owen WJ. Effect of omeprazole $20 \mathrm{mg}$ twice daily on duodenogastric and gastro-oesophageal bile reflux in Barrett's esophagus. Gut 1998;43:603-6.

38. Stein HJ, Kauer WK, Feussner H, Siewert JR. Bile reflux in benign and malignant Barrett's esophagus: effect of medical acid suppression and Nissen fundoplication. J Gastrointest Surg 1998;2:333-41.

39. Romero Y, Cameron AJ, Locke GR III, et al. Familial aggregation of gastroesophageal reflux in patients with Barrett's esophagus and esophageal adenocarcinoma. Gastroenterology 1997;113:1449-56.

40. Trudgill NJ, Kapur KC, Riley SA. Familial clustering of reflux symptoms. Am J Gastroenterol 1999;94:1172-8.

41. al-Kasspoules M, Moore JH, Orringer MB, Beer DG. Amplification and over-expression of the EGFR and erbB-2 genes in human esophageal adenocarcinomas. Int J Cancer 1993;54:213-9.

42. Brito MJ, Filipe MI, Linehan J, Jankowski J. Association of transforming growth factor alpha (TGFA) and its precursors with malignant change in Barrett's epithelium: biological and clinical variables. Int J Cancer 1995;60:27-32.

43. Jankowski J, Hopwood D, Wormsley KG. Flow-cytometric analysis of growth-regulatory peptides and their receptors in Barrett's oesophagus and oesophageal adenocarcinoma. Scand J Gastroenterol $1992 ; 27: 147-54$.

44. Zbroch T, Weston AP, Badr AS, Marcinkiewicz M, Poplawski C, Sariosek J. The elevated content of epidermal growth factor and transforming growth factor $\alpha$, and diminished prostaglandin $E_{2}$ in fasting gastric juice in patients with Barrett's esophagus: their potential pathogenetic implications. Gastroenterology 1998;114:A345. (Abst)

45. Silberg DG, Furth EE, Taylor JK, Schuck T, Chiou T, Traber PG. CDX1 protein expression in normal, metaplastic, and neoplastic human alimentary tract epithelium. Gastroenterology 1997;113:478-86.

46. van Lieshout EMM, Jansen JBMJ, Peters WHM. Glutathione and 
glutathione S-transferases in Barrett's epithelium. Gastroenterology 1998;114:A321. (Abst)

47. van Lieshout EM, Roelofs HM, Dekker S, et al. Polymorphic expression of the glutathione S-transferase P1 gene and its susceptibility to Barrett's esophagus and esophageal carcinoma. Cancer Res 1999;59:586-9.

48. Hong MK, Laskin WB, Herman BE, et al. Expansion of the Ki-67 proliferative compartment correlates with degree of dysplasia in Barrett's esophagus. Cancer 1995;75:423-9.

49. Reid BJ, Blount PL, Rubin CE, Levine DS, Haggitt RC, Rabinovitch PS. Flow-cytometric and histological progression to malignancy in Barrett's esophagus: prospective endoscopic surveillance of a cohort. Gastroenterology 1992;102:1212-9.

50. Younes M, Lebovitz RM, Lechago LV, Lechago J. p53 protein accumulation in Barrett's metaplasia, dysplasia, and carcinoma: a follow-up study. Gastroenterology 1993;105:1637-42.

51. Falk GW. Endoscopic surveillance of Barrett's esophagus: risk stratification and cancer risk. Gastrointest Endosc 1999;49:S29-34.

52. Sampliner RE, Fass R. Partial regression of Barrett's esophagus an inadequate endpoint. Am J Gastroenterol 1993;88:2092-4.

53. Garewal H, Ramsey L, Sharma P, Fass R, Kraus K, Sampliner R. Complete reversal of Barrett's esophagus: biomarker studies indicate decreased cancer risk in a biologically normal squamous epithelium. Gastroenterology 1998;114:A129. (Abst)

54. Garewal H, Ramsey L, Sharma P, Fass R, Morales T, Sampliner R. Squamous islands in Barrett's esophagus: biomarker studies suggest continued increased risk. Gastroenterology 1998;114:A129. (Abst)

55. Wang KK, Nijhawan P, Nourbakhsh A, Lutzke L, WongKeeSong M, Anderson M. Does residual Barrett's esophagus progress after photodynamic therapy. Gastroenterology 1999;116:A348. (Abst)

56. Streitz JM Jr, Andrews CW Jr, Ellis FH Jr. Endoscopic surveillance of Barrett's esophagus. Does it help? J Thorac Cardiovasc Surg 1993;105:383-8.

57. Peters JH, Clark GW, Ireland AP, Chandrasoma P, Smyrk TC, DeMeester TR. Outcome of adenocarcinoma arising in Barrett's esophagus in endoscopically surveyed and nonsurveyed patients. J Thorac Cardiovasc Surg 1994;108:813-22.

58. Canto MI, Setrakian S, Petras RE, Blades E, Chak A, Sivak MV Jr. Methylene blue selectively stains intestinal metaplasia in Barrett's esophagus. Gastrointest Endosc 1996;44:1-7.

59. Falk JW, Ours TM, Richter JE. Practice patterns for surveillance of Barrett's esophagus in the USA. Gastrointest Endosc 1999;49:AB50. (Abst)

60. Gray MR, Donnelly RJ, Kingsnorth AN. The role of smoking and alcohol in metaplasia and cancer risk in Barrett's columnar lined oesophagus. Gut 1993;34:727-31.

61. Cooper BT, Barbezat GO. Treatment of Barrett's esophagus with $\mathrm{H}_{2}$ blockers. J Clin Gastroenterol 1987:9:139-41.

62. Hameeteman W, Tytgat GN. Healing of chronic Barrett ulcers with omeprazole. Am J Gastroenterol 1986;81:764-6.

63. Sontag SJ, Schnell TG, Chejfec G, Kurucar C, Karpf J, Levine G. Lansoprazole heals erosive reflux esophagitis in patients with Barrett's esophagus. Aliment Pharmacol Ther 1997;11:147-56.

64. Stein HJ, Hoeft S, DeMeester TR. Functional foregut abnormalities in Barrett's esophagus. J Thorac Cardiovasc Surg 1993;105:107-11.

65. Katzka DA, Castell DO. Successful elimination of reflux symptoms does not insure adequate control of acid reflux in patients with Barrett's esophagus. Am J Gastroenterol 1994;89:989-91.

66. Wesdorp IC, Bartelsman J, Schipper ME, Tytgat GN. Effect of long-term treatment with cimetidine and antacids in Barrett's esophagus. Gut 1981;22:724-7.

67. Sampliner RE, Garewal HS, Fennerty MB, Aickin M. Lack of impact of therapy on extent of Barrett's esophagus in 67 patients. Dig Dis Sci 1990;35:93-6.

68. Sharma P, Sampliner RE, Camargo E. Normalization of esophageal pH with high-dose proton inhibitor therapy does not result in regression of Barrett's esophagus. Am J Gastroenterol 1997;92:582-5.

69. Ortiz A, Martinez de Haro LF, Parrilla P, et al. Conservative treatment versus antireflux surgery in Barrett's oesophagus: long-term results of a prospective study. Br J Surg 1996;83:274-8.

70. DeMeester TR, Attwood SE, Smyrk TC, Therkildsen DH, Hinder RA. Surgical therapy in Barrett's esophagus. Ann Surg 1990;212:528-42.

71. DeMeester TR, Bonavina L, Albertucci M. Nissen fundoplication for gastroesophageal disease: Evaluation of primary repair in 100 consecutive patients. Ann Surg 1986;204:9-20.

72. Brand DL, Ylvisaker JT, Gelfand M, Pope CE II. Regression of columnar esophageal (Barrett's) epithelium after anti-reflux surgery. N Engl J Med 1980;302:844-8.

73. Williamson WA, Ellis FH Jr, Gibb SP, Shahian DM, Aretz HT. Effect of antireflux operation on Barrett's mucosa. Ann Thorac Surg 1990;49:537-542.

74. Attwood SE, Barlow AP, Norris TL, Watson A. Barrett's oesophagus: effect of antireflux surgery on symptom control and development of complications. Br J Surg 1992;79:1050-3.

75. Sagar PM, Ackroyd R, Hosie KB, Patterson JE, Stoddard CJ, Kingsnorth AN. Regression and progression of Barrett's oesophagus after antireflux surgery. Br J Surg 1995;82:806-10.

76. Low DE, Levine DS, Dail DH, Kozarek RA. Histological and anatomic changes in Barrett's esophagus after antireflux surgery. Am J Gastroenterol 1999;94:80-5.

77. Hamilton SR, Hutcheon DF, Ravich WJ, Cameron JL, Paulson M. Adenocarcinoma in Barrett's esophagus after elimination of gastroesophageal reflux. Gastroenterology 1984;86:356-60.

78. Skinner DB. Controversies about Barrett's esophagus. Ann Thorac Surg 1990;49:523-4.

79. McDonald ML, Trastek VF, Allen MS, Deschamps C, Pairolero PC, Pairolero PC. Barretts's esophagus: does an antireflux procedure reduce the need for endoscopic surveillance? J Thorac Cardiovasc Surg 1996;111:1135-40.

80. Csendes A, Braghetto I, Burdiles P, et al. Long-term results of classic antireflux surgery in 152 patients with Barrett's esophagus: clinical, radiologic, endoscopic, manometric, and acid reflux test analysis before and late after operation. Surgery 1998;123:645-57.

81. Salo JA, Salminen JT, Kiviluoto TA, et al. Treatment of Barrett's esophagus by endoscopic laser ablation and antireflux surgery. Ann Surg 1998;227:40-4.

82. Altorki NK, Sunagawa M, Little AG, Skinner DB. High-grade dysplasia in the columnar-lined esophagus. Am J Surg 1991;161:97-100.

83. Pera M, Trastek VF, Carpenter HA, Allen MS, Deschamps C, Pairolero PC. Barrett's esophagus with high-grade dysplasia: an indication for esophagectomy? Ann Thorac Surg 1992;54:199-204.

84. Rice TW, Falk GW, Achkar E, Petras RE. Surgical management of high-grade dysplasia in Barrett's esophagus. Am J Gastroenterol 1993;88:1832-6.

85. Edwards MJ, Gable DR, Lentsch AB, Richardson JD. The rationale for esophagectomy as the optimal therapy for Barrett's esophagus with high-grade dysplasia. Ann Surg 1996;223:585-91.

86. Heitmiller RF, Redmond M, Hamilton SR. Barrett's esophagus with high-grade dysplasia. An indication for prophylactic esophagectomy. Ann Surg 1996;224:66-71.

87. Ferguson MK, Naunheim KS. Resection for Barrett's mucosa with high-grade dysplasia: implications for prophylactic photodynamic therapy. J Thorac Cardiovasc Surg 1997;114:824-9.

88. Levine DS, Haggitt RC, Blount PL, Rabinovitch PS, Rusch VW, Reid BJ. An endoscopic biopsy protocol can differentiate high-grade dysplasia from early adenocarcinoma in Barrett's esophagus. Gastroenterology 1993;105:40-50.

89. Levine DS, Haggitt RC, Irvine S, et al. Natural history of high grade dysplasia in Barrett's esophagus. Gastroenterology 1996;110:A550. (Abst)

90. Schnell T, Sontag SJ, Chejfec G, et al. Barrett's, high grade dysplasia (HGD): surveillance endoscopy (EGD) once a year (YR) is sufficient in most patients (pts). Gastroenterology 1999;116:A304. (Abst)

91. Sampliner RE. Ablative therapies for the columnar-lined esophagus. Gastroenterol Clin North Am 1997;26:685-94.

92. Lightdale CJ. Ablation therapy for Barrett's esophagus: is it time to choose our weapons? Gastrointest Endosc 1999;49:122-5.

93. Soehendra N, Binmoeller KF, Bohnacker S, et al. Endoscopic snare mucosectomy in the esophagus without any additional equipment: a simple technique for resection of flat early cancer. Endoscopy 1997;29:380-3.

94. Overholt BF, Panjehpour M, Haydek JM. Photodynamic therapy for Barrett's esophagus: follow-up in 100 patients. Gastrointest Endosc 1999;49:1-7.

95. Barr H, Shepherd NA, Dix A, Roberts DJ, Tan WC, Krasner N. Eradication of high-grade dysplasia in columnar-lined (Barrett's) oesophagus by photodynamic therapy with endogenously generated protoporphyrin IX. Lancet 1996;348:584-5. 
96. Ortner M, Zumbusch K, Liebetruth J, et al. Photodynamic therapy of Barrett's esophagus after local administration of 5-aminolevulinic acid. Gastroenterology 1997;112:A633. (Abst)

97. Wang KK, WongKeeSong LM, Nourbakhsh A, et al. Controlled trial of low dose photodynamic therapy for Barrett's esophagus. Gastroenterology 1997;112:A676. (Abst)

98. Gossner L, Stolte M, Sroka R, et al. Photodynamic ablation of high-grade dysplasia and early cancer in Barrett's esophagus by means of 5-aminolevulinic acid. Gastroenterology 1998;1998;114:448-55.

99. Gossner L, May A, Stolte M, Seitz G, Hahn EG, Ell C. KTP laser destruction of dysplasia and early cancer in columnar-lined Barrett's esophagus. Gastrointest Endosc 1999;49:8-12.

100. Sampliner RE, Fennerty B, Garewal HS. Reversal of Barrett's esophagus with acid suppression and multipolar electrocoagulation: preliminary results. Gastrointest Endosc 1996;44:532-5.

101. Guelrud M, Herrera I. Multipolar electrocoagulation in the treatment of Barrett's esophagus. Gastrointest Endosc 1997;45:AB69. (Abst)

102. Van Laetham JL, Cremer M, Peny MO, Delhaye M, Deviere J.
Eradication of Barrett's mucosa with argon plasma coagulation and acid suppression: immediate and mid term results. Gut 1998;43:747-51.

103. Byrne JP, Armstrong GR, Attwood SE. Restoration of the normal squamous lining in Barrett's esophagus by argon beam plasma coagulation. Am J Gastroenterol 1998;93:1810-5.

104. Luman W, Lessels AM, Palmer KR. Failure of Nd-YAG photocoagulation therapy as treatment for Barrett's oesophagus a pilot study. Eur J Gastroenterol Hepatol 1996;8:627-30.

105. Krevsky B, Horwitz B, Cohen S, Fisher RS. Long-term effects of acid suppression on Nd-YAG laser treated Barrett's esophagus: ongoing studies. Gastroenterology 1998;114:A188-9. (Abst)

106. Berenson MM, Johnson TD, Markowitz NR, Buchi KN, Samowitz W. Restoration of squamous mucosa after ablation of Barrett's esophageal epithelium. Gastroenterology 1993;104:1686-91.

107. Barham CP, Jones RL, Biddlestone LR, Hardwick RH, Shepherd NA, Barr H. Photothermal laser ablation of Barrett's oesophagus: endoscopic and histological evidence of squamous re-epithelialisation. Gut 1997;41:281-4. 


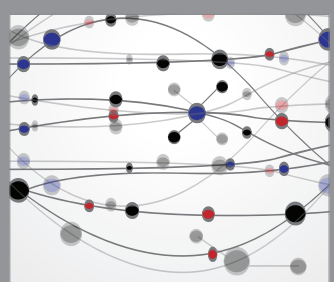

The Scientific World Journal
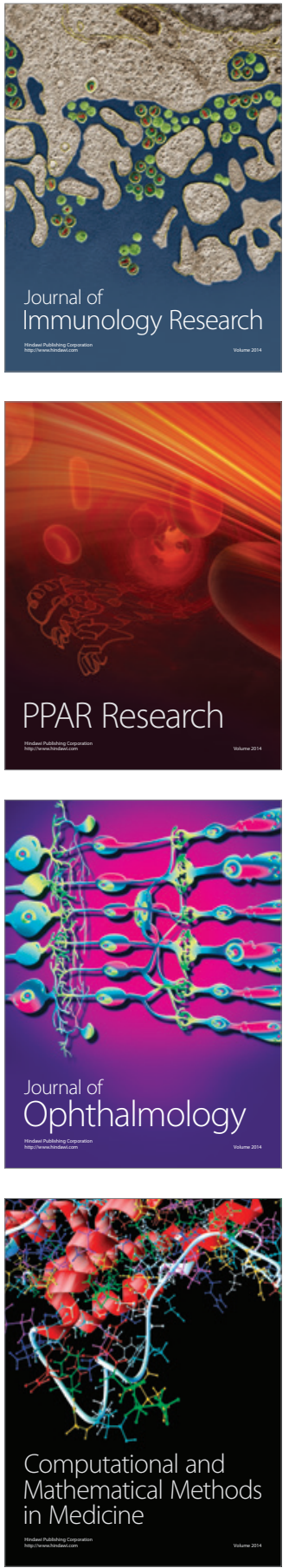

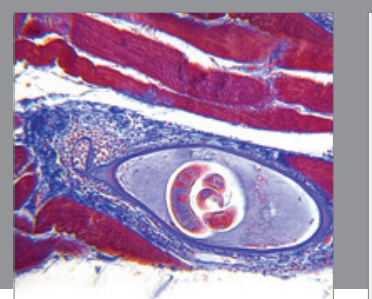

Gastroenterology Research and Practice

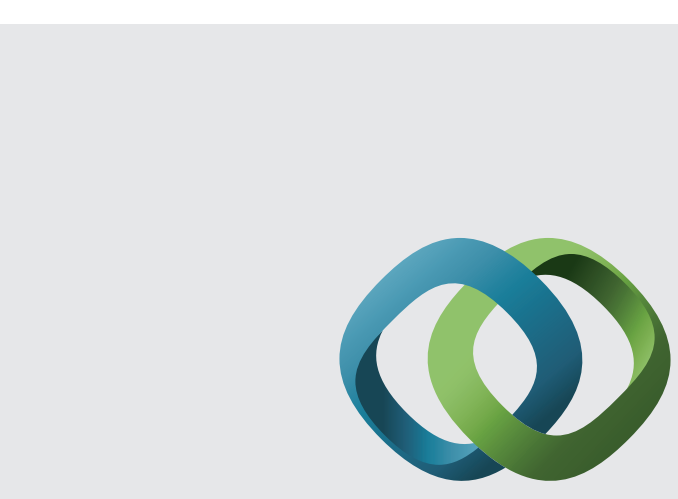

\section{Hindawi}

Submit your manuscripts at

http://www.hindawi.com
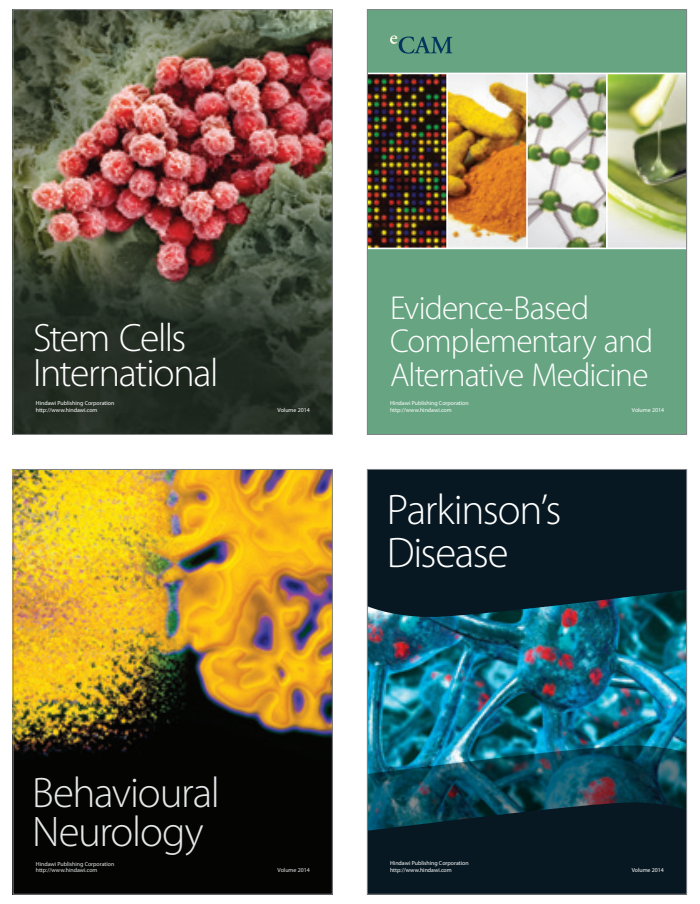
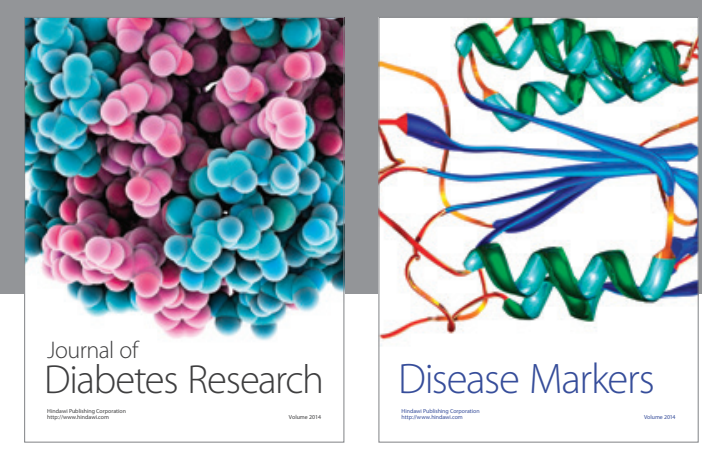

Disease Markers
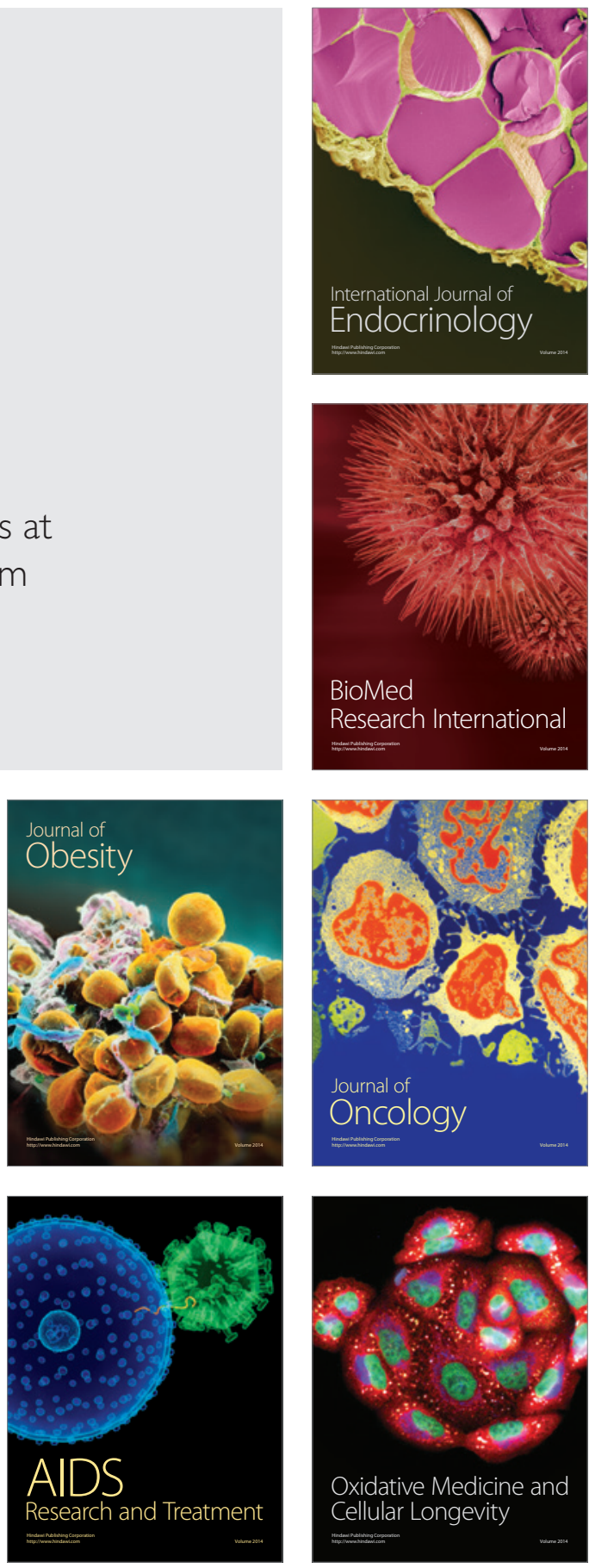